\title{
The Potential of EMSA Eritin to Modulate T Cells (CD4+ and CD8+) in Balb/C Mice Model of Diabetes Mellitus
}

\author{
Ade Meylisa Crystel Rohie ${ }^{1}$, Muhaimin Rifa'i ${ }^{2 *}$ \\ ${ }^{1}$ Master Program of Biology, Faculty of Mathematics and Natural Sciences, University of Brawijaya, Malang, Indonesia \\ ${ }^{2}$ Department of Biology, Faculty of Mathematics and Natural Sciences, University of Brawijaya, Malang, Indonesia
}

\begin{abstract}
EMSA Eritin is a medicinal polyherbal contains with soy bean, coconut water and red rice extract. In several studies of this individual components have proven the potential to modulate lymphocyte cells that indirectly lowering blood glucose levels in diabetes meliitus. This study was aimed to analyzing the effect of polyherbal EMSA Eritin on the expression of $\mathrm{CD}^{+}, \mathrm{CD}^{+}$and SDF-1 cells population in mice model of diabetes mellitus. Neonatal d-5 mice was intraperitoneally injected with Streptozotocin (STZ) $100 \mathrm{mg} \cdot \mathrm{kg}^{-1}$

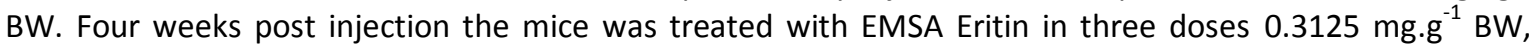
$3.125 \mathrm{mg} . \mathrm{g}^{-1}$ BW and $31.25 \mathrm{mg} \cdot \mathrm{g}^{-1}$ BW for 14 days. Cells Profile of T lymphocyte $\left(\mathrm{CD}^{+}\right.$and $\left.\mathrm{CD} 8^{+}\right)$and chemokine SDF-1 were analyzed by Flow cytometry. Data were analyzed with One-way ANOVA $(p<0.05)$ and Duncan test using SPSS 16.0 for Windows. The result showed that EMSA Eritin significantly increased T lymphocyte $\left(\mathrm{CD}^{+}\right.$and $\left.\mathrm{CD} 8^{+}\right)$in optimum dose $3.125 \mathrm{mg} \cdot \mathrm{g}^{-1} \mathrm{BW}$ and suppress SDF-1 production in high dose (31.25 mg. $\mathrm{g}^{-1} \mathrm{BW}$ ) as well as the blood glucose level measurement. This study suggest that polyherbal EMSA Eritin has a potential to decreased blood glucose level in mice model of diabetes mellitus.
\end{abstract}

Keywords: $\mathrm{CD}^{+}, \mathrm{CD}^{+}$, diabetes mellitus, EMSA Eritin, SDF-1

\section{INTRODUCTION}

Diabetes mellitus (DM) has become one of the major causes of morbidity and mortality in the world with increasing prevalence where 3.4 million people died in 2004. It is predicted to be doubled in 2030 which makes this metabolic disorder one of the leading death cause in the world. Diabetes mellitus is a metabolic disease characterized by hyperglycemia, caused by the loss of glucose homeostasis in blood [1,2].

Diabetes has a several complications that can cause systemic disorders in some organs, including cellular immune system, e.g. lymphocytes, monocytes, neutrophils and macrophages that can lead to cell death [3]. Some studies suggest that patients with diabetes have an increased apoptotic cell death in lymphocyte from the peripheral blood vessels, and other pathogens. Influence exerted by reduced the number of $\mathrm{CD}^{+}$and $\mathrm{CD} 8^{+} \mathrm{T}$ cells and also affecting lymphopoiesis $[4,5,6] . \mathrm{CD}^{+}$is a marker in T cell known as T-helper cell that can help activate $B$ cells to

\footnotetext{
* Correspondence author:

Muhaimin Rifa'i

Email : rifa123@ub.ac.id

Address : Laboratory of Animal Physiology, Department of Biology, University of Brawijaya, Jl. Veteran Malang, 65145
}

secrete antibodies and macrophages to destroy foreign substance, and also activated $\mathrm{CD}^{+}$ known as T-cytotoxic cell to kill infected target cells. $\mathrm{CD}^{+} \mathrm{T}$ cells along with $\mathrm{CD} 8^{+} \mathrm{T}$ cells make up the majority of T-lymphocytes and plays important roles in immune system [7]. Immune system dysfunction in diabetic patients also occurs in polymorphonuclear cells (PMN) such as chemotaxis and phagocytosis as well [8]. Chemotaxis as a chemoattractant are postulated to help direct lymphocyte traffic into sites of inflammation and into lymphoid and non-lymphoid tissues during recirculation. Stromal cell-derived factor-1 or SDF-1 is known to be a highly efficacious chemoattractant for $\mathrm{T}$ lymphocytes and has a complex effects on migration, proliferation, and differentiation of leukocytes [9]. Reduced number of $T$ lymphocytes in patients with diabetes mellitus caused by hyperglycemia that increase reactive oxygen species (ROS) and excess produce of superoxide in the body. This immune disorders are known to be a stressor that affects the immune modulation and play an important pathogenic role in immunodeficiency $[10,11]$.

In traditional medicine, a mixture of several species of herbs known as poliherbal has comprising prescriptions that can improve body defense mechanisms [12]. EMSA Eritin is a mixture of three edible medicinal herbal, consist 
of soybean (Glycine max), water coconut (Cocos nucifera) and red rice (Oryza sp.) extract. Several studies of EMSA Eritin individual components have proven they have a potential to lowering blood glucose levels in diabetes mellitus [13-16]. This study was aimed to determine the expression of $\mathrm{CD}^{+}, \mathrm{CD}^{+}$and SDF-1 cells population in thymus of mice (Mus musculus) model of diabetes mellitus after EMSA Eritin administration.

\section{MATERIALS AND METHODS \\ Mice}

In this study we used a total 25 neonatal 5day-old Balb/C mice with \pm 2.5 g body weight. Mice were taken care in free pahtogen animal chamber, Departement of Biology, Faculty of Mathematic and Natural Sciences, University of Brawijaya, Malang, East Java, Indonesia.

This research has obtained an ethical clearence certificate from Brawijaya University Research Ethics Committee. No: KEP-385-UB.

\section{Induction of Diabetes mellitus}

Neonatal d-5 Balb/C mice was intraperitoneally injected with $50 \mu \mathrm{L}$ Streptozotocin 100 $\mathrm{mg} . \mathrm{kg}^{-1} \mathrm{BW}(0.005 \mathrm{mg} \mathrm{STZ}$ was dissolved in $1 \mathrm{~mL}$ of $0,1 \mathrm{M}$ citrate buffer $\mathrm{pH} 4.5$ ) [17]. Mice were divided into five experiment group; three treatment group (low, optimum and high doses) and two control group (positive and negative). Mice from all treatment group and positive control group were injected with STZ. Blood glucose level then measure when mice at the ages 4-5 weeks post injection.

\section{Administration of EMSA Eritin}

Polyherbal EMSA Eritin was given orally for 14 days in three group doses: low dose $(0.3125$ $\left.\mathrm{mg} \cdot \mathrm{g}^{-1} \mathrm{BW}\right)$, optimum dose (3.125 $\mathrm{mg} \cdot \mathrm{g}^{-1} \mathrm{BW}$ ) and high dose (31.25 mg. $\left.\mathrm{g}^{-1} \mathrm{BW}\right)$. Determination of EMSA Eritin doses for each treatment group were based on the human consumption of $60 \mathrm{~kg} \mathrm{BW}$ that consumed about $15 \mathrm{~g}$ of EMSA Eritin. Polyherbal EMSA Eritin was derived from Royal Medicalink Pharmalab Company, Makassar, Indonesia.

\section{Blood Glucose Measurement}

Measurement of blood glucose levels was done every three days with One Touch Ultra(C) glucometer. Blood sampling was taken from the mice tails, blood was dropped in the glucostick and wait for the value appear on the glucometer screen. Mice with blood glucose levels over than
$200 \mathrm{mg} \cdot \mathrm{dl}^{-1}$ is declared as a type 2 diabetes mellitus [18].

\section{Cell Isolation from Thymus}

Lymphocyte and chemokine cells was isolated from thymus. Mice were killed by cervical dislocation and surgery with an incision in the abdominal region of mice. Thymus was cleaned, crushed and filtered with PBS to separate from fat tissue. The suspension then put into polypropylene tube and added with PBS until $10 \mathrm{~mL}$ and put it in centrifuge $(2500 \mathrm{rpm}$ for $5 \mathrm{~min}$ at $\left.4^{\circ} \mathrm{C}\right)$. The supernatant was discarded and the obtained pellet was resuspensed with $1 \mathrm{~mL}$ PBS, and put into micro tube, added PBS and centrifuged again (2500 rpm for $5 \mathrm{~min}$ at $4^{\circ} \mathrm{C}$ ). The suspended cells ready to proceed for intracellular staining.

\section{Intracellular Staining and Flowcytometry}

Intracellular staining was performed from the suspended isolation cells and incubated with 40 $\mu \mathrm{L}$ antibody (FITC-conjugated anti-mouse CD4, PE-conjugated anti-mouse CD8) Catalogue No. 100531, 100708, BioLegend, San Diego, CA, USA for 20 minutes. After incubation, resuspended using $100 \mu \mathrm{L}$ cytofix buffer and incubated for 20 minutes in dark condition, at $4^{\circ} \mathrm{C}$. Sample then resuspended with $500 \mu \mathrm{L}$ wash-perm and centrifuged (2500 rpm at $4^{\circ} \mathrm{C}$ for $5 \mathrm{~min}$ ). The supernatant was discarded and pellet was added with PE-Cy5-conjugated anti-mouse SDF-1 (Catalogue No. IC350C, BioLegend, San Diego, CA, USA) and incubated for 20 minutes. Sample then added with $300 \mu \mathrm{L}$ of PBS, transferred into flow cytometry cuvette and ready for running with $\mathrm{BD}$ Biosciences FACS Calibur ${ }^{\mathrm{TM}}$ nozzle flow cytometry using BD CellQuest software settings PRO ${ }^{T M}$.

\section{Statistical Analysis}

Data from this study were analyzed statistically by One way ANOVA (Analysis of Variance) with $p<0.05$ to assess the statistical difference between experiment group and continued with Duncan test using SPSS 16.0 for Windows.

\section{RESULT AND DISCUSSION Blood Glucose level}

Blood glucose level is the amount of glucose that present and transported through the bloodstream to supply energy to all the cells in our bodies. The body naturally regulates blood glucose levels as a part of metabolic homeostatis. Based on obtained data from treatment and 
control group of the blood glucose levels measurements showed a varying result (Fig. 1). Blood glucose levels in NON-DM group still on the normal range between 95-134 mg.dL ${ }^{-1}$ whereas blood glucose levels in DM group was approved to be a hyperglycemia because it is over than $200 \mathrm{mg} \cdot \mathrm{dL}^{-1}$ [18]. The treatment group at low dose $\left(0.3125 \mathrm{mg} \cdot \mathrm{g}^{-1} \mathrm{BW}\right)$ showed a fluctuated blood glucose levels. The blood glucoe level was decreased from the start and increased at the $12^{\text {th }}$ day of measurement, as well as the high dose (31.25 mg.g ${ }^{-1} \mathrm{BW}$ ) level of blood glucose was extremely fluctuated with final measurement blood glucose level are 133.8 $\mathrm{mg} \cdot \mathrm{dL}^{-1}$. While the treatment group at optimum dose (3.125 mg. $\mathrm{g}^{-1} \mathrm{BW}$ ) showed a gradually decrease blood sugar levels even though the final measurement blood glucose level is $231 \mathrm{mg} \cdot \mathrm{dL}^{-1}$. The mean result of statistical analysis showed there are significantly different blood glucose level between the treatment and control group $(p<0.05)$, even though there are no significant difference within the treatment group $(p>0.05)$.

The changes of blood sugar level may be influenced by several factors, for example the endurance from each mice to response free radicals that damage the pancreas due to STZ injection, hormonal factors in the body that affect insulin production and environmental factors such as stress that suffered from the treatment [19].

\section{Profile Population of T cells $\mathrm{CD} 4^{+}$and $\mathrm{CD} 8^{+}$}

$\mathrm{T}$ cells $\mathrm{CD}^{+}$and $\mathrm{CD}^{+}$is a trans membrane protein that has a function as co-receptor on $T$ lymphocytes with a different roles. $T$ cells populating the peripheral blood or secondary lymphoid organs were distinguished by the expression of $\mathrm{CD}^{+}$and $\mathrm{CD} 8^{+} \mathrm{T}$ cells based on the use of particular monoclonal antibodies. The expression of $\mathrm{CD}^{+}$and $\mathrm{CD}^{+}$was linked to different $T$ cell functions; in the case of $\mathrm{CD} 4^{+}$ known as T-helper, augmenting the ability of $B$ cells to produce antibodies and help activate other immune cell including $\mathrm{CD}^{+} \mathrm{T}$ cell that known as T-cytotoxic cell causing direct cytotoxicity of infected target cell. T lymphocyte cell derived from hematopoietic stem cell (HSC) in bone marrow (BM) and differentiated into lymphoid progenitor became precursor $\mathrm{T}$ cells and migrate from BM to thymus for further maturation became $T$ cells mature single positive $\left(\mathrm{CD}^{+}\right.$and $\left.\mathrm{CD}^{+}\right)$. The development of primary $\mathrm{CD}^{+} \mathrm{T}$ cell responses is thought to be assisted directly by $\mathrm{CD}^{+} \mathrm{T}$ cells in two ways; the activation of professional APC and the secretion of cytokines [7,8].

Based on $T$ lymphocytes relative number from flow cytometry analysis (Fig. 2), the entire experimental group in a healthy state because $\mathrm{CD}^{+} \mathrm{T}$ cell population is higher than $\mathrm{CD} 8^{+} \mathrm{T}$ cell population [20]. T Cells Population of $\mathrm{CD}^{+}$and $\mathrm{CD}^{+}$in all treatment group was increased compare to DM control group, the relative number of $\mathrm{CD}^{+} \mathrm{T}$ cell treatment group as follows; DM-D1 (0.3125 mg. $\left.\mathrm{g}^{-1} \mathrm{BW}\right)$ 12.69\%, DMD2 (3.125 mg.g ${ }^{-1}$ BW) 15.19\%, and DM-D3 (31.25 mg.g ${ }^{-1}$ BW) $13,32 \%$ has increased compare to DM group. Same condition in $\mathrm{CD}^{+} \mathrm{T}$ cell population relative number as follows; DM-D1 (0.3125 mg.g ${ }^{-1}$ BW) 5.12\%, DM-D2 (3.125 mg.g ${ }^{-1}$ BW) 5.43\%, and DM-D3 (31.25 mg.g ${ }^{-1}$ BW) 4, 52\% also increased from DM group. The relative number of $\mathrm{T}$ cell $\mathrm{CD}^{+}$and $\mathrm{CD}^{+}$population in all treatment group was significantly increased compare to DM group $(p<0.05)$, although there are no significantly differences within the treatment group.

The increasing of $\mathrm{T}$ cell $\mathrm{CD}^{+}$and $\mathrm{CD}^{+}$ population in thymus after administration of EMSA Eritin was assumed because of the antioxidants compound such as flavonoids and anthocyanin that contained in soy beans and red rice extract. The possible mechanisms $[12,13,15]$, antioxidant is known to have a role as an immunomodulatory that is able to induce and increase the secretion of cytokines IFN- $\nu$ to produce IL-2 that may involved in cell activation of $\mathrm{T}$ lymphocytes. The increased cell activation is caused by flavonol glycosides in flavonoids that can act as a mitogen and induced timosit to stimulate the secretion of cytokines which will increase the receptor expression of mature $T$ lymphocytes $\left(\mathrm{CD} 4^{+}\right.$and $\left.\mathrm{CD} 8^{+}\right)$. Another content of active compounds such as saponins also able to play a role in triggering the activation of IFN- $\gamma$. Which in turn stimulates the expression of MHCII, thereby increasing the $\mathrm{CD} 4^{+} \mathrm{T}$ cell proliferation which affect the $\mathrm{CD}^{+} \mathrm{T}$ cell activation [21,22]. Exposed naïve $T$ antigen and antigen presented by APC will develop into a subset of T cells $C D 4^{+}$ and $\mathrm{CD} 8^{+} . \mathrm{CD}^{+} \mathrm{T}$ cells will develop into Th1 and Th2 subsets, where Th1 is contributed to the production of cytokines IL-2 and IFN- $\gamma$ which activate the $\mathrm{CD}^{+} \mathrm{T}$ cell immune cell function. Mechanism action of $\mathrm{CD}^{+}$as a modulator of the immune system derived from the activity of some cytokines such as IL-1, IL-2 and IFN- $\gamma$ also to induce $\mathrm{CD} 8^{+} \mathrm{T}$ cell maturation $[23,24]$. 


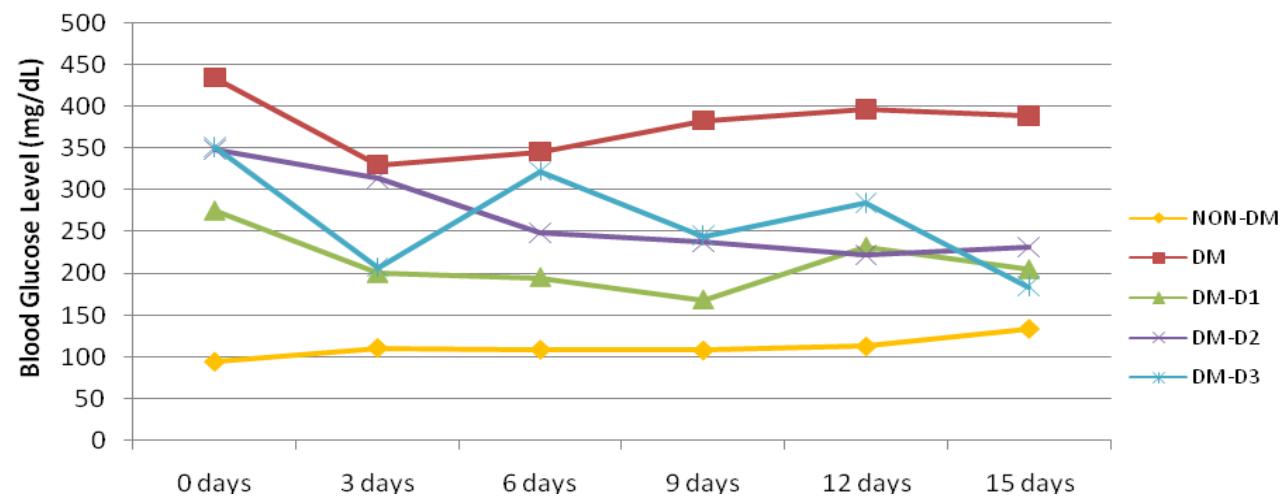

Figure 1. Measurement of blood glucose level. (NON-DM) nondiabetic mice as negative control group without any treatment. (DM) diabetic mice as positive control group, treated with injection of Streptozotocin $100 \mathrm{mg} \cdot \mathrm{kg}^{-1}$. (DMD1) DM mice treated with EMSA Eritin at low dose $0.3125 \mathrm{mg} \cdot \mathrm{g}^{-1} \mathrm{BW}$. (DM-D2) DM mice treated with EMSA Eritin at optimum dose $3.125 \mathrm{mg} \cdot \mathrm{g}^{-1} \mathrm{BW}$. (DM-D3) DM mice treated with EMSA Eritin at high dose $31.25 \mathrm{mg} \cdot \mathrm{g}^{-1} \mathrm{BW}$.
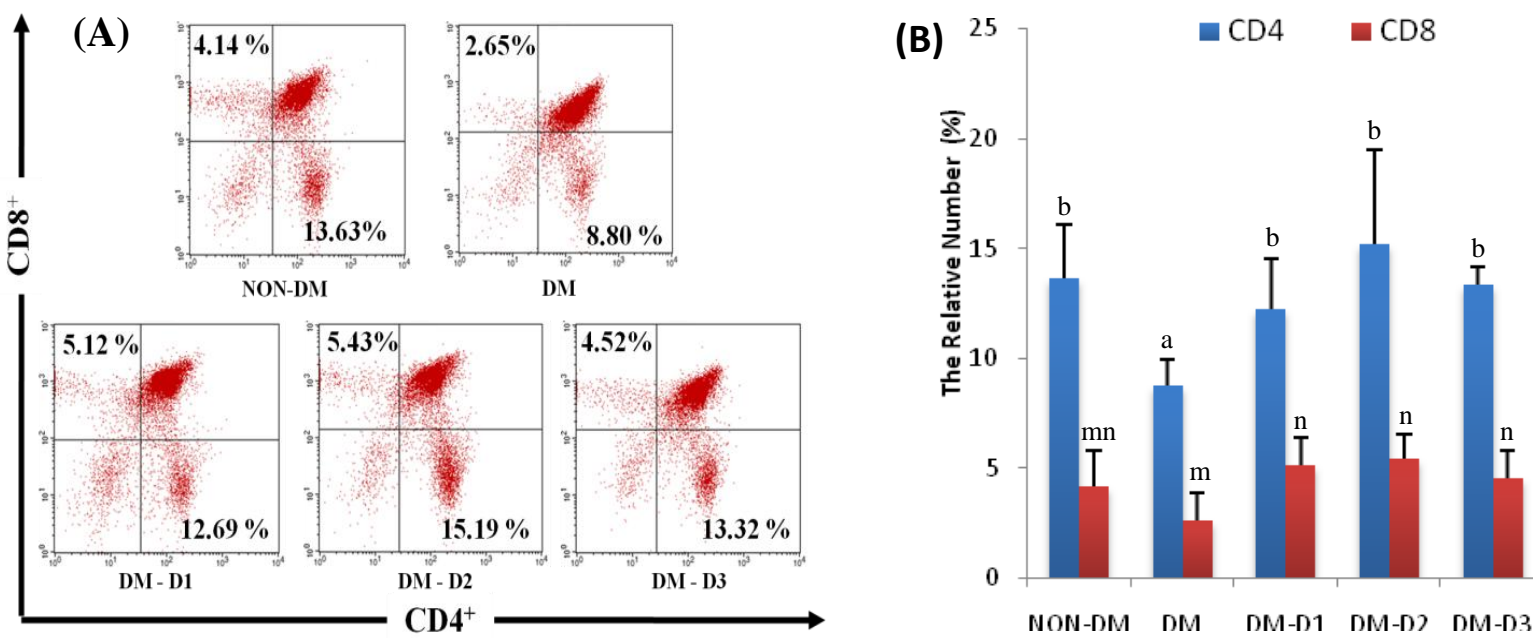

Figure 2. Cells population of $\mathrm{CD}^{+}$and $\mathrm{CD}^{+} \mathrm{T}$ cells were increased in all treatment group. (A) The results of flow-cytometry analysis (B) Mean of percentage relative number from five group. Differences notation indicates significant difference $(p<0.05)$. (NON-DM) nondiabetic mice as negative control group without any treatment. (DM) diabetic

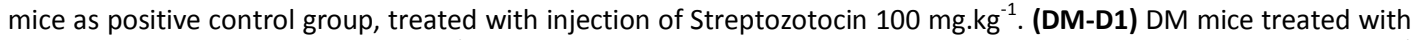
EMSA Eritin at low dose $0.3125 \mathrm{mg} \cdot \mathrm{g}^{-1} \mathrm{BW}$. (DM-D2) DM mice treated with EMSA Eritin at optimum dose $3.125 \mathrm{mg} \cdot \mathrm{g}^{-1}$ BW. (DM-D3) DM mice treated with EMSA Eritin at high dose $31.25 \mathrm{mg} \cdot \mathrm{g}^{-1} \mathrm{BW}$.

\section{Profile Population of SDF-1 Chemokine}

Stromal Cell-Derived Factor-1 (SDF-1), is a CXC chemokine stromal derived from bone marrow. Chemokines are a family on chemoattratractant polypeptides that classified into 4 groups, depend on the position of conserved cysteine residues. Chemokines mediate their effect by binding to transmembrane $\mathrm{G}$ protein-coupled co-receptors CXCR4. Major role of chemokines is chemoattractant to guide the migration of cells. Chemokines-attracted cells follow a signal of increasing chemokine concentration towards the source. Some chemokines control mobilization cells of the immune system during processes of immune surveillance such as leukocyte subsets to inflammation sites $[25,26]$.
Flowcytometry analysis and relative number of SDF-1 cells showed varying results between the group. SDF-1 relative number increased gradually in DM-D1 and DM-D2 but decreased in high dose (DM-D3) $0.69 \%$. The relative number of SDF-1 cells population was significantly differences between treatment and control group $(p<0.05)$ (Fig. 3). Increased population of SDF-1 in DM-D2 (3.125 mg.g ${ }^{-1}$ BW) $1.76 \%$ presumably cause by the expression of SDF-1 as chemoattractant. It released signal by injured cells or tisue in thymus lead to increased level of SDF-1 at the inflammation site. While in high dose (31.25 mg.g ${ }^{-1} \mathrm{BW}$ ), expression of SDF-1 decreased probably due to recovery from the active compound flavonoid from soy bean (G. max) as an antioxidant at the site of inflammation [21]. 
(A)
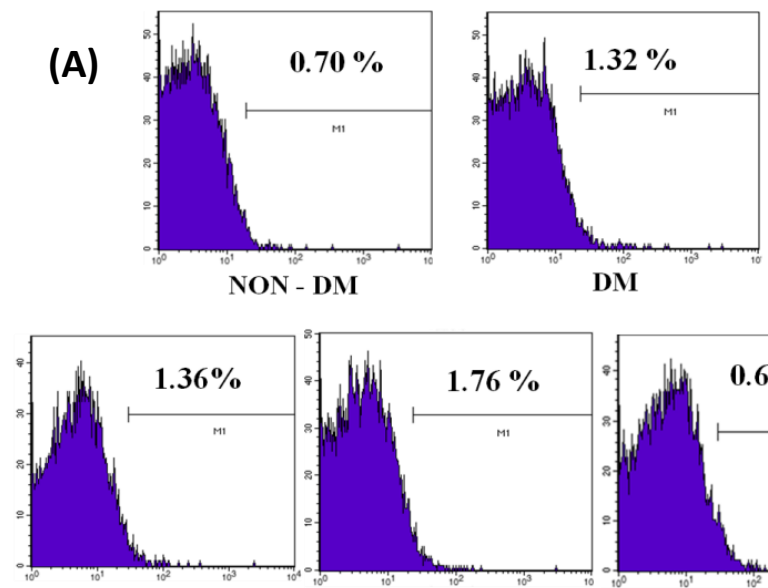

DM - D1

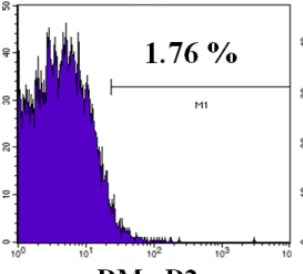

DM - D2

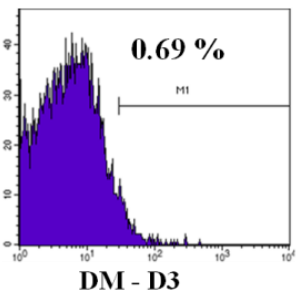

SDF-1
(B)

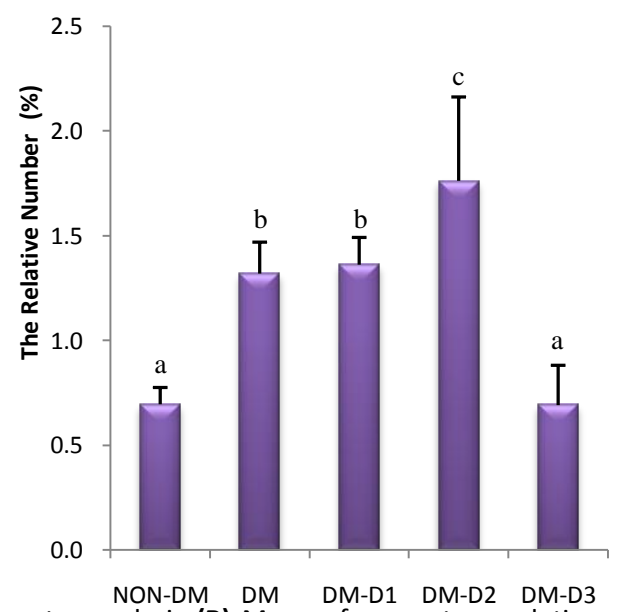

Figure 3. Cells population of SDF-1 in thymus. (A) The results of flow-cytometry analysis (B) Mean of percentage relative number from five group. Differences notation indicates significant difference $(p<0.05)$. (NON-DM) nondiabetic mice as negative control group without any treatment. (DM) diabetic mice as positive control group, treated with injection of Streptozotocin $100 \mathrm{mg} \cdot \mathrm{kg}^{-1}$. (DM-D1) DM mice treated with EMSA Eritin at low dose $0.3125 \mathrm{mg} \cdot \mathrm{g}^{-1} \mathrm{BW}$. (DM-D2) DM mice treated with EMSA Eritin at optimum dose $3.125 \mathrm{mg} \cdot \mathrm{g}^{-1}$ BW. (DM-D3) DM mice treated with EMSA Eritin at high dose $31.25 \mathrm{mg} \cdot \mathrm{g}^{-1} \mathrm{BW}$.

Polyherbal EMSA Eritin is known to have antioxidant form of isoflavones and anthocyanins derived from soy beans and red rice extract. Isoflavones are flavonoid group commonly found in soybeans and has beneficial effect on diabetic patients by eliminating the direct oxygen free radicals, increasing the concentration of antioxidant enzymes and increases serum insulin and pancreatic insulin component [13]. Genistein, a component of isoflavones, have the effect of lowering blood glucose by increasing insulin production and glucose uptake by cells [14]. Just like isoflavones, anthocyanins protect pancreatic cells from oxidative stress, lowers blood glucose levels by increasing insulin receptors work, improve antioxidant status by pressing malondialdehyde and improve the level of superoxide dismutase [16]. Compared to individual component from different studies, polyherbal EMSA Eritin can also lowering the blood glucose through the improvement of T lymphocyte cell $\left(\mathrm{CD}^{+}\right.$and $\left.\mathrm{CD}^{+}\right)$and chemokine SDF-1 modulation in thymus mice model of diabetes mellitus in this experiment.

\section{CONCLUSION}

Polyherbal EMSA Eritin can modulate T lymphocytes $\left(\mathrm{CD}^{+}\right.$and $\left.\mathrm{CDB}^{+}\right)$in optimum dose $3.125 \mathrm{mg} . \mathrm{g}^{-1} \mathrm{BW}$ and supress SDF-1production in high dose (31.25 mg.g ${ }^{-1}$ BW) as well as the blood glucose level measurement. This study suggest that EMSA Eritin is a potential polyherbal that can be used as a therapy for diabetes.

\section{ACKNOWLEDGEMENT}

The author would like to thank Royal Medicalink Pharmalab company to fund this research, Maic Audo Lin Sihombing S.Si as research partner and the entire team of Laboratory of Animal Physiology.

\section{REFERENCES}

[1] Centers for Disease Control and Prevention. 2014. National diabetes statistics report: estimates of diabetes and its burden in the United States. Department of Health and Human Services. Atlanta, GA:US.

[2] American Diabetes Association. 2014. Diagnosis and classification of diabetes mellitus. Diabetes Care. 37(1). S81-590.

[3] Fujiyama, M., K. Nagaishi, T. Yamashita, K. Ataka. 2012. Bone marrow stem cell abnormality and diabetic complications. Anat. Rec. 295. 917-921.

[4] Salih, F. 2012. Lymphocytes apoptosis in type 2 diabetes mellitus. Iraqi J. Comm. Med. 4. 330-332.

[5] Abdelrazaq, A.A., W.H. Yousif, S.A.Wohaieb. 2013. Flow cytometric analysis of CD4 and CD8 $T$ cell subsets in some Iraqi patients with Diabetes Mellitus Type 2. Current Res. Microbiol. Biotechnol. 1(5). 235-238. 
[6] Otton, R., F.G. Soriano, R. Verlengia, R. Curi, 2004. Diabetes induces apoptosis in lymphocytes. J. Endocrinol. 182. 145-156.

[7] Abbas, A.K., A.H. Licthman. 2005. Immunity to tumours. In: Cellular and Molecular Immunology $5^{\text {th }}$ Edition. WB Saunders Co. Philadelphia.

[8] Geerlings, S.E., A.I.M. Hoepelman. 1999. Immune dysfunction in patients with diabetes mellitus (DM). FEMS Immunol. Med. Microbiol. 26. 259-265.

[9] Bleul, C.C., R.C. Fuhlbrigge, J.M.C.A. Aiuti, T.A. Springer. 1996. A highly efficacious lymphocyte chemoattractant, Stromal Cellderived Factor 1 (SDF-1). J. Exp. Med. 184. 1101-1109.

[10] Rosen P., P.P. Nawroth, G. King, W. Moller, H.J. Tritschler, L. Packer. 2001. The role of oxidative stress in the onset and progression of diabetes and its complications: a summary of a Congress Series sponsored by UNESCO-MCBN, the American Diabetes Association and the German Diabetes Society. Diabetes Metab. Res. Rev. 17. 189212.

[11] Rubinstein, R., A.M. Genaro, A. Motta, G. Cremaschi, M.R. Wald. 2008. Impaired immune responses in streptozotocininduced type I diabetes in mice: involvement of high glucose. British Soc. Immunoly, Clin. Exp. Immunol. 154. 235-246.

[12] Park, H.R., S.K. Jo, U. Jung, S.T. Yee. 2008. Restoration of the immune functions in aged mice by supplementation with a new herbal composition, HemoHIM. Phytother. Res. 22(1). 36-42.

[13] Sada N.M., Y. Tanko, M.A. Mabrouk. 2013. Effect of soya beans supplement on blood glucose levels and haematological indices on alloxan induced diabetic wistar rats. Ann. Biol. Res. 4(2).208-213.

[14] Gupta, R., S.B. Sharma. 2012. Effect of germinated Glycine max seeds on glycemic control in STZ+NAD induced type 2 diabetic models: a preliminary study. J. Exp. Integr. Med. 2(2). 155-160.

[15] Preetha, P.P., V. Girija-Devi, T. Rajamohan. 2013. Comparative effects of mature coconut water (Cocos nucifera) and glibenclamide on some biochemical parameters in alloxan induced diabetic rats. Brazilian J. Pharmacognosy. 23(3). 481-487.

[16] Han, H.K., S.S. Choi, J.C Shin, H.S. Chung. 2008. Lipid lowering effect of anthocyaninpigmented rice bran in Streptozotocin- induced diabetic male rats. J. Food Sci. Nutr. 13. 276-280.

[17] Srinivasan, K. P. Ramarao. 2007. Animal models in type 2 diabetes research: An overview. Indian J. Med. Res. 125. 451-472.

[18] Perkumpulan Endokrinologi Indonesia. 2011. Konsensus pengendalian dan pencegahan diabetes mellitus tipe 2 di Indonesia 2011. PERKENI. 1-10.

[19] Santoso, B.I. 2001. Fisiologi manusia: dari sel ke sistem. EGC. Jakarta.

[20] Rifa'i, M. 2013. Imunologi dan alergihypersensitif. UB Press. Malang.

[21] Middleton, E., C. Kandaswami, T.C. Theoharides. 2000. The effect of plant flavonoids on mammalian cells implication for inflammation, heart disease and cancer. J. Pharmacol. 52(4). 673-751.

[22] Lyu, S.Y., W.B. Park. 2005. Production of cytokine and NO By RAW264.7 macrophages and PBMC in vitro incubation with flavonoids. Arch. Pharm. Res. 28. 573-581.

[23] Baratawidjaja, KG., R. Iris. 2010. Basic immunology $9^{\text {th }}$ edition. Faculty of Medical, University of Indonesia. Jakarta.

[24] Rifa'i, M., Z. Shi, S.Y. Zhang, Y.H. Lee, H. Shiku, K. Isobe, H. Suzuki. 2008. CD8+CD12+ regulatory $T$ cells recognize activated $T$ cells via conventional MHC Class $1-\alpha \beta T C R$ interaction and become IL-10-Producing Active Regulatory Cells. Int. Immunol. 20. 937-947.

[25] Ma, Q., D. Jones, P.R. Borghesant, R.A. Segal, T. Nagasawa, T. Kishimoto, R.T. Bronsoni, T.A. Springer. 1998. Impaired Blymphopoiesis, myelopoiesis, and derailed cerebellar neuron migration in CXCR4- and SDF-1-deficient mice. Proc. Natl. Acad. Sci. 95. 9448-9453.

[26] Dunussi-Joannopoulos, K., K. Zuberek, K. Runyon, R.G. Hawley, A. Wong, J. Erickson, S. Herrmann, J.P. Leonard. 2002. Efficacious immunomodulatory activity of the chemokine Stromal Cell-Derived Factor 1 (SDF-1): local secretion of SDF-1 at the tumor site serves as T-cell chemoattractant and mediates T-cell-dependent antitumor responses. Blood J. 100(5). 1551-1558. 